\title{
STANDING TO SUE IN ANTITRUST CASES: THE OFFENSIVE USE OF PASSING-ON
}

\section{INTRODUCTION}

Section 4 of the Clayton $\mathrm{Act}^{1}$ authorizes a private right of action for violation of the antitrust laws. It is clear and simple on its face:

Any person who shall be injured in his business or property by reason of anything forbidden in the antitrust laws may sue therefore in any district court of the United States in the district in which the defendant resides or is found or has an agent, without respect to the amount in controversy, and shall recover threefold the damages by him sustained, and the cost of suit, including a reasonable attorney's fee.

A two-part standing test with seeming general application has been promulgated by the Supreme Court. The first part is the traditional "case or controversy" requirement. ${ }^{2}$ The second part provides that if "injury in fact" is alleged, an individual has standing to sue when "the interest sought to be protected by the complainant is arguably within the zone of interests to be protected or regulated by the statute or constitutional guarantee in question." ${ }^{3}$ In the antitrust context the Court has stated that the antitrust laws were designed to

protect the victims of the forbidden practices as well as the public. ... Furthermore, Congress itself has placed the private antitrust litigant in a most favorable position through the enactment of $\S 5$ of the Clayton Act. ... In the face of such a policy this Court should not add requirements to burden the private litigant beyond what is specifically set forth by Congress in those laws. ${ }^{4}$

Given the Act and the Supreme Court's general statements about standing and the purpose of the Act, it would seem that a liberal

${ }^{1} 15$ U.S.C. $\S 15$ (1970).

2 See Flast v. Cohen, 392 U.S. 83 (1968).

${ }^{3}$ Association of Data Processing Serv. Organizations, Inc. v. Camp, 397 U.S. 150 (1970).

${ }^{4}$ Radovich v. National Football League, 352 U.S. 445, 454 (1957). 
policy of granting standing in antitrust cases would be mandated. Such a policy, however, is still in the process of evolution.

An examination of cases dealing with standing under the Clayton Act does not reveal any consistent pattern. However, two basic tests of "interests sought to be protected" have arisen, one focusing on the directness of the injury complained of and the other focusing on the "target" of the violation. Both had their genesis ${ }^{5}$ in Loeb v. Eastman Kodak Co. ${ }^{6}$ The plaintiff, a stockholder and creditor of a bankrupt corporation, alleged that the defendant's antitrust violations caused him losses in both capacities. The court dismissed the suit, holding that the plaintiff's injury was "indirect, remote, and consequential,"7 and that "[n]o conspiracy or combination against him as a stockholder or creditor [was] alleged." the proximate cause analysis of tort law) has been employed to deny standing in antitrust cases to shareholders of an injured corporation, ${ }^{9}$ creditors of injured debtors, ${ }^{10}$ lessors of injured lessees, ${ }^{11}$ and patentees of injured licensees. ${ }^{12}$ Implied in the direct injury analysis is a requirement of privity. ${ }^{13}$

Currently more favored is the target-area analysis, ${ }^{14}$ in which the plaintiff need only show that he was "within that area

s Pollock, Standing to Sue, Remoteness of Injury and the Passing-On Doctrine, 32 A.B.A. Antitrust L.J. 5, 12 (1966).

6 183 F. 704 (3d Cir. 1910).

${ }^{7} I d$. at 709 .

${ }^{8}$ Id.

"See, e.g., Walker Distrib. Co. v. Lucky Lager Brewing Co., 323 F.2d 1 (9th Cir. 1963); Bookout v. Schine Chain Theaters, Inc., 253 F.2d 292 (2d Cir. 1958); Martens v. Barrett, 245 F.2d 844 (5th Cir. 1957). Cf. Volasco Prods. Co. v. Lloyd A. Fry Roofing Co., 308 F.2d 383 (6th Cir. 1962), cert. denied, 372 U.S. 907 (1963).

${ }^{10}$ See, e.g., Walker Distrib. Co. v. Lucky Lager Brewing Co., 323 F.2d 1 (9th Cir. 1963); Gerli v. Silk Ass'n of America, 36 F.2d 959 (S.D.N.Y. 1929); W'estmoreland Asbestos Co. v. Johns-Manville Corp., 30 F. Supp. 389 (S.D.N.Y.), aff'd on reargument, 32 F. Supp. 731 (S.D.N.Y. 1939), aff'd, 113 F.2d 114 (2d Cir. 1940).

${ }^{11}$ See, e.g., Melrose Realty Co. v. Loew's Inc., 234 F.2d 518 (3d Cir.), cert. denied, 352 U.S. 890 (1956); United Copper Sec. Co. v. Amalgamated Copper Co., 232 F. 574 (2d Cir. 1916); Lieberthal v. North Country Lanes, Inc., 221 F. Supp. 685 (S.D.N.Y. 1963), aff'd, 332 F.2d 269 (2d Cir. 1964); Harrison v. Paramount Pictures, Inc., 115 F. Supp. 312 (E.D. Pa. 1953), aff'd, 211 F.2d 405 (3d Cir.), cert. denied, 348 U.S. 828 (1954).

${ }^{12}$ See, e.g., SCM Corp. v. Radio Corp. of America. 407 F.2d 166 (2d Cir.), cert. denied, 395 U.S. 943 (1969); Productive Inventions, Inc. v. Trico Prods. Corp.. 224 F.2d 678 (2d Cir. 1955), cert. denied, 350 U.S. 936 (1956).

${ }^{13}$ Comment, Mangano and the Ultimat'-Consumer Standing: The Misuse of the Hanover Doctrine, 72 Colum. L. Rev. 394, 399 (1972).

14 See, e.g., Klingsberg, Bull's Eyes and Carom Shots: Complications and Conflicts on Standing to Sue and Causation under Section 4 of the Clayton Act, 16 ANTITRUst Bull. 351,359 (1971). 
of the economy which is endangered by a breakdown of competitive conditions in a particular industry." 15 Under this analysis suppliers, ${ }^{16}$ employees, ${ }^{17}$ and a shareholder-employee ${ }^{18}$ have been accorded standing. Moreover, in Mulvey v. Samuel Goldwyn Productions ${ }^{19}$ the Ninth Circuit took a broader view, holding that the target area principle includes plaintiffs whose injury was reasonably forseeable.

The terms "direct," "remote," "target," and "foreseeable" are not the most precise, however, and standing under the Clayton Act has traditionally been mired in confusion. ${ }^{20}$ Determining who has standing to sue under the antitrust laws is further complicated by the far-reaching consequences of any interference in a complex and interdependent economic system. An illegal overcharge determined at the manufacturing level can cause distortions throughout the chain of distribution. Depending on elasticities of demand, a distributor may be forced to absorb the extra cost or he may be able to pass part or all of it along to his customers, who in turn must examine their markets to determine their own reaction to the increased costs. It is evident, then, that any antitrust violation which leads to higher prices generates a number of potential plaintiffs spread throughout the chain of distribution. Under the terms of section 4 of the Clayton Act, it would seem that any of these potential plaintiffs should be accorded standing to bring suit. Even a relatively strict view of the target-area approach could not logically restrict any person in the chain of distribution. ${ }^{21}$ It is clear

${ }^{15}$ Conference of Studio Unions v. Loew's Inc., 193 F.2d 51, 55 (9th Cir. 1951). cert. denied, 342 U.S. 919 (1952).

${ }^{16}$ South Carolina Council of Milk Producers, Inc. v. Newton, 360 F.2d 414 (4th Cir.), cert. denied, 385 U.S. 934 (1966); Karseal Corp. v. Richfield Oil Corp., 221 F.2d 358 (9th Cir. 1955).

${ }^{17}$ Wilson v. Ringsby Truck Lines. Inc., 320 F. Supp. 699 (D. Colo. 1970); Schroeter v. Ralph Wilson Plastics, Inc., 49 F.R.D. 323 (S.D.N.Y. 1969).

${ }^{18}$ Schroeter v. Ralph Wilson Plastics, Inc., 49 F.R.D. 323 (S.D.N.Y. 1969).

19 433 F.2d 1073 (9th Cir. 1970), cert. denied, 402 U.S. 923 (1971).

${ }^{20}$ For a list of some of the considerations which have entered into standing decisions, see Handler, The Shift From Substantive to Procedural Innovations in Antitrust Suits-The Tu'enty-Third Annual Antitrust Revieu, 71 Colum. L. Rev. 1, 30-31 (1971).

${ }^{21}$ Twentieth Century Fox Film Corp. v. Goldwyn, 328 F.2d 190 (9th Cir.), cert. denied, 379 U.S. 880 (1964); Washington v. American Pipe \& Constr. Co., 274 F. Supp. 961 (D. Hawaii 1967). See Atlantic City Elec. Co. v. General Elec. Co., 226 F. Supp. 59, 71 (S.D.N.Y.), appeal denied, 337 F.2d 844 (2d Cir. 1964); McGuire, The PassingOn Defense and the Right of Remote Purchasers to Recover Treble Damages under Hanover Shoe, 33 U. PITt. L. Rev. 177, 183 (1971); Pollock, Automatic Treble Damages and the Passing-On Defense: The Hanover Shoe Decision, I3 ANTIrRust Bull. 1183, 1188 (1968). 
that such a person's operations would lie "in the area which it could reasonably be foreseen would be affected by the conspiracy."22

Nevertheless, in the wake of Hanover Shoe, Inc. $v$. United Shoe Machinery Corp. ${ }^{23}$ there has arisen a theory of standing based on the presumption that in certain cases plaintiffs who are not direct purchasers from violators will be faced with such insurmountable difficulties of proof that they should not even be allowed to try to establish their injuries. Although the question has received the attention of other commentators, a number of recent cases $^{24}$ have departed from earlier judicial interpretations of Hanover Shoe and thus provide a fitting occasion for a re-examination of the problem.

\section{The Impact of Hanover Shoe}

\section{A. Hanover Shoe and the Passing-On Defense}

Hanover Shoe was a private treble-damage action by a shoe manufacturer against a manufacturer of shoe machinery pursuant to section 4 of the Clayton Act. Plaintiff Hanover Shoe alleged that defendant's policy of leasing, but refusing to sell, its shoe manufacturing equipment resulted in illegal overcharges in the price it had to pay to use the machinery. Defendant United Shoe contended that Hanover was not injured within the terms of section 4 because it had passed on any overcharge by raising the price of its shoes. After the lower courts had rejected this argument, ${ }^{25}$ the Supreme Court granted certiorari to consider, inter alia, whether the lower court's rejection of the defense was proper.

The Court held that rejection of the passing-on defense was proper. In so concluding, it implicitly recognized the possibility that a plaintiff who in fact had not been injured might recover. ${ }^{26}$

${ }^{22}$ Twentieth Century Fox Film Corp. v. Goldwyn, 328 F.2d 190, 220 (9th Cir.). cert. denied, 379 U.S. 880 (1964).

${ }^{23} 392$ U.S. 481 (1968).

${ }^{24}$ In re Western Liquid Asphalt Cases, 487 F.2d 191 (9th Cir. 1973), cert. denied, 415 U.S. 919 (1974); In re Master Key Antitrust Litigation, 1973-2 Trade Cas. 174,680 (D. Conn. 1973); Boshes v. General Motors Corp., 59 F.R.D. 589 (N.D. Ill. 1973).

${ }^{25}$ The procedural history of the case is rather interesting. At a special hearing prior to trial; Judge Goodrich rejected the passing-on defense as a matter of law. Hanover Shoe, Inc. v. United Shoe Mach. Corp., 185 F. Supp. 826 (M.D. Pa.), aff'd per curiam on interloculory appeal, 281 F.2d 481 (3d Cir.), cert. denied, 364 U.S. 901 (1960). Trial resulted in judgment for the plaintiff. 245 F. Supp. 258 (M.D. Pa. 1965), vacated on the issue of damages, 377 F.2d 776 (3d Cir.), modified, 392 U.S. 481 (1968).

${ }^{26}$ If in the face of the overcharge the buyer does nothing and absorbs the loss, 
The Court employed three separate grounds to support such a result.

The first was based on the general principal that the "victim of an overcharge is damaged within the meaning of $\S 4$ to the extent of that overcharge." 27 This principle was derived by the Court from a brief examination of five cases decided between 1906 and 1931: Chattanooga Foundry and Pipe Works v. City of Atlanta, ${ }^{28}$ Thomsen v. Cayser, ${ }^{29}$ Southern Pacific Co. v. Darnell-Taenzer Lumber Co., ${ }^{30}$ Keogh v. Chicago E N.W. Railway, ${ }^{31}$ and Adams $v$. Mills. ${ }^{32}$ The Court seemed to rely most upon the opinions of Justice Holmes in the Chattanooga and Darnell-Taenzer cases. In Chattanooga the city of Atlanta sought to recover treble damages for overcharges on the price of iron pipe for its waterworks. The Court affirmed a judgment for the city for an amount measured by the difference between the price actually paid and what the price would have been absent the conspiracy. The Court reasoned that the city "was injured in its property, at least, if not in its business of furnishing water, by being led to pay more than the worth of the pipe. A person whose property

he is entitled to treble damages. This much seems conceded. The reason is that he has paid more than he should and his property has been illegally diminished, for had the price paid been lower his profits would have been higher. It is also clear that if the buyer, responding to the illegal price, maintains his own price but takes steps to increase his volume or to decrease other costs, his right to damages is not destroyed. Though he may manage to maintain his profit level, he would have made more if his purchases from the defendant had cost him less. We hold that the buyer is equally entitled to damages if he raises the price for his own product. As long as the seller continues to charge the illegal price, he takes from the buyer more than the law allows. At whatever price the buyer sells, the price he pays the seller remains illegally high, and his profits would be greater were his costs lower.

392 U.S. at 489.

This argument is based on the premise either that the plaintiff firm is charging its customers the highest price possible consistent with producing the highest margin of profit possible, and that if it passes on the overcharge the result will be a reduction in profits, or that if, for some economically irrational reason, the plaintiff's price is lower than it should be and the overcharge does not, therefore, reduce its profits the plaintiff will still be losing profits it could have been making.

As pointed out by United Shoe, this argument ignores those situations where the conspiracy affects all of the plaintiff's effective competitors and where the demand for the product is inelastic. 392 U.S. at 491-92. In that case plaintiff can pass on the overcharge and suffer no loss. Given inelastic demand, total sales will not decrease; and given equal effect on all firms at one level, no firm will lose its proportional share of the market.

27392 U.S. at 491.

${ }^{28} 203$ U.S. 390 (1906).

2: 243 U.S. 66 (1917).

30245 U.S. 531 (1918).

${ }^{31} 260$ U.S. 156 (1922).

32286 U.S. 397 (1932). 
is diminished by a payment of money wrongfully induced is injured in his property." 33 Further, "when a man is made poorer by an extravagant bill we do not regard his wealth as a unity, or the tort, if there is one, as directed against that unity as an object. We do not go behind the person of the sufferer."34

The reasoning in Chattanooga can be described most charitably as conclusory. However, this dearth of analysis was remedied somewhat in Darnell-Taenzer. That case involved an action for reparations brought against a railroad by shippers claiming damages resulting from the railroad's charging of an unreasonable rate. The defendants argued that the shippers passed on to their customers the difference between the rate charged and a reasonable one. The Court replied:

The answer is not difficult. The general tendency of the law, in regard to damages at least, is not to go beyond the first step. As it does not attribute remote consequences to a defendant so it holds him liable if proximately the plaintiff has suffered a loss. The plaintiff suffered losses to the amount of the verdict when they paid. Their claim accrued at once in the theory of the law and it does not inquire into latter events ... . The carrier ought not to be allowed to retain his illegal profit, and the only one who can take it from him is the one that alone was in relation with him, and from whom the carrier took the sum.... Behind the technical mode of statement is the consideration ... of the endlessness and futility of the effort to follow every transaction to its ultimate result. ... Probably in the end the public pays the damages in most cases of compensated torts. ${ }^{35}$

Thus Holmes' conclusion rests on two observations. First, the party first in line in the chain of distribution is the only available plaintiff who can enforce the policy of the antitrust laws because he is the only party in privity with the violator. ${ }^{36}$ Sec-

\footnotetext{
${ }^{33} 203$ U.S. at 396.

${ }^{34}$ Id. at 399.

35 245 U.S. at 533-34.

${ }^{36}$ If it be said that the whole transaction is one from a business point of view, it is enough to reply that the unity in this case is not sufficient to entitle the purchaser to recover, any more than the ultimate consumer who in turn paid an increased price. He has no privity with the carrier.
}

245 U.S. at 534. The Court's deletion of this language from its rather lengthy quotation from the case suggests an intention not to breathe new life into the privity concept. See 392 U.S. at 490-91 n.8; Comment, The Effect of Hanover Shoe on the Offensive Use of the Passing-On Doctrine, 46 S. CALif. L. Rev. 98, 110 (1972). 
ond, the offense should be considered complete at the time of the injury because this is a convenient point at which to end the examination; therefore, no examination into remote consequences is required..$^{37}$

The privity question was not before the Court in Hanover Shoe and it is extremely doubtful that the Court intended to reinstate that questionable doctrine as part of antitrust standing analysis. ${ }^{38}$ Thus, the Holmes decisions were relied upon mainly as support for the proposition that an examination into the remote consequences of an injury should be limited. As the rest of the opinion makes clear, this limitation is justified because it relieves somewhat the burden placed on the courts by complicated antitrust cases ${ }^{39}$ and because inquiry into the plaintiff's behavior in consequence of his injury would weaken the enforcement of the antitrust laws. ${ }^{40}$

The Court's second reason for refusing to permit a passingon defense was that the task of establishing the preconditions necessary for its valid application is, effectively, an impossible one:

A wide range of factors influence a company's pricing policies. Normally the impact of a single change in the relevant conditions cannot be measured after the fact; indeed a businessman may be unable to state whether, had one fact been different (a single supply less expensive, general economic conditions more buoyant, or the labor market tighter, for example), he would have chosen a different price. Equally difficult to determine, in the real economic world rather than an economist's hypothetical model, is what effect a change in a company's price will have on its total sales. Finally, costs per unit for a different volume of total sales are hard to estimate. Even if it could be shown that the buyer raised his price in response to, and in the amount

${ }^{37} 245$ U.S. at 533-34.

${ }^{38}$ Cases holding that privity is not a requirement under $\S 4$ of the Clayton Act are numerous. See, e.g., In re Multidistrict Vehicle Air Pollution, 481 F.2d 122, 129 (9th Cir.), cert. denied, 414 U.S. 1045 (1973); Dailey v. Quality School Plan, Inc., 380 F.2d 484 (5th Cir. 1967); South Carolina Council of Milk Producers, Inc. v. Newton. 360 F.2d 414 (4th Cir.), cert. denied, 385 U.S. 934 (1966); Karseal Corp. v. Richfield Oil Corp., 221 F.2d 358 (9th Cir. 1955); Vines v. General Outdoor Advertising Co., 171 F.2d 487 (2d Cir. 1948); Clark Oil Co. v. Phillips Petroleum Co., 148 F.2d 580 (8th Cir.), cert. denied, 326 U.S. 743 (1945); Wilson v. Ringsby Truck Lines, Inc., 320 F. Supp. 699 (D. Colo. 1970); Washington v. General Elec. Co., 246 F. Supp. 960 (W.D. Wash. 1965).

${ }^{39}$ See 392 U.S. at 493.

${ }^{40} I d$. at 494 . 
of, the overcharge and that his margin of profit and total sales had not thereafter declined, there would remain the nearly insuperable difficulty of demonstrating that the particular plaintiff could not or would not have raised his prices absent the overcharge or maintained the higher price had the overcharge been discontinued. Since establishing the applicability of the passing-on defense would require a convincing showing of each of these virtually unascertainable figures, the task would normally prove insurmountable. ${ }^{41}$

Not content with concluding that a defendant could not prove that the overcharge was passed on even if he tried, the Court reasoned further that, if the defense were available, defendants would jump at this opportunity to prove the impossible with the result that "[t]reble-damage actions would often require additional long and complicated proceedings involving massive evidence and complicated theories." 42

This "problems of proof" rationale lends itself to at least two interpretations. First, it might be argued that the Court held, with minor exceptions, ${ }^{43}$ that it is impossible for defendants to prove a pass-on and that this is so as a matter of law. The more sensible conclusion is that the Court's statement should not be read too literally and that its primary concern was in insulating the lower courts from fact-finding burdens that would severely hamper the effectiveness of section 4 as an enforcement mechanism for the antitrust laws. This second view finds support in the Court's somewhat disingenuous statement that allowing the pass-on defense would bog down the proceedings in complications, implying that antitrust cases do not otherwise require "massive evidence and complicated theories." 44

Given this latter interpretation, the argument can be considered as a corollary to the Court's third ground for the rejection of the defense: the need to protect the effectiveness of the treble damage remedy. The Court reasoned that to allow the passing-on defense would remove the best plaintiff from the controversy and would leave the enforcement of the antitrust laws to parties with little interest in so doing:

[The] ultimate consumers, in today's case the buyers of single pairs of shoes, would have only a tiny stake

${ }^{41}$ Id. at 492-93 (footnote omitted).

42 Id. at 493.

${ }^{43}$ See text accompanying notes $46-48$ infra.

4392 U.S. at 493. 
in a lawsuit and little interest in attempting a class action. In consequence, those who violate the antitrust laws ... would retain the fruits of their illegality because no one was available who would bring suit against them. Trebledamage actions, the importance of which the Court has many times emphasized, would be substantially reduced in effectiveness. ${ }^{45}$

The Court's indictment of the passing-on defense was not total, however. The Court indicated that it might approve the defense in situations where the "overcharged buyer has a preexisting 'cost-plus' contract, thus making it easy to prove that he has not been damaged ... ."46 The cost-plus contract is an arrangement by which a party is completely reimbursed for its costs and is paid a fixed fee above cost as its profit. In such a case "the considerations requiring that the passing-on defense not be permitted . . . would not be present." ${ }^{47}$

${ }^{45} I d$. at 494 .

${ }^{46} I d$.

${ }^{47}$ Id. The Court also indicated that the inquiry in price discrimination cases arising under the Robinson-Patman Act might not be properly measured solely by reference to the amount of the overcharge.

There is considerable controversy as to the proper measure of damages in a price discrimination case. Based on a policy of more effective deterrence, the Ninth Circuit has held that "unless the evidence establishes a greater consequential inquiry, discrimination in prices or allowances is entitled to be regarded as constituting a direct business injury and that the amount thereof thus properly can be made the basis and measure of a general damage award." Fowler Mfg. Co. v. Gorlick, 415 F.2d 1248, 1252 (9th Cir. 1969) (footnote omitted), cert. denied, 396 U.S. 1012 (1970). Contra, Enterprise Indus., Inc. v. Texas Co., 240 F.2d 457 (2d Cir.) (opinion by L. Hand, J.), cert. denied, 353 U.S. 965 (1957) (finding that the measure of damages is proven loss of business).

The argument for adhering to the Hand formulation in discrimination cases while holding to the Hanover formula for overcharge cases has been put quite lucidly by one commentator:

Overcharge cases like Hanover Shoe are readily distinguished from the Robinson-Patman Act cases. In the former, plaintiff's proof that he was overcharged because of an antitrust violation is sufficient to establish a prima facie case. Hanover Shoe simply goes one step farther-it excludes evidence designed to rebut that case. In the Robinson-Patman context, the disfavored buyer does not claim that the price which he paid was of itself unlawful; his grievance is that his competitors were charged a lower price, and that such price discrimination is unlawful. It does not follow that the disfavored buyer should be allowed to recover upon a mere showing of price discrimination. He must also show that the price discrimination enabled a favored competitor to lower its resale price and thus to take business away from him. If instead the favored competitor merely pocketed the price difference and refused to lower its resale prices, the disfavored buyer might suffer no injury. [Therefore] such a buyer does not establish a prima facie case when he establishes a price discrimination. 


\section{B. Passing-On Prior to Hanover Shoe}

Hanover Shoe dealt with passing-on as a defense. The problem under examination here is passing-on as a theory of recovery: "offensive passing-on." Before examining the effect of that case on the right to prove that overcharges were passed on, it should be helpful to examine the state of the law prior to Hanover Shoe.

Earlier courts treated the question of an indirect purchaser's right to sue primarily as one of privity. ${ }^{48}$ In Washington v. General Electric Co. ${ }^{49}$ the defendants were charged with a conspiracy which resulted in overcharges for generators used in hydroelectric projects. The state of Washington sued for treble damages, alleging that the original purchasers, the general contractors, had passed on the overcharges in their bids for the hydroelectric project. The defendant manufacturers moved to dismiss on the ground that there was no privity of contract between themselves and the plaintiff. The court, unimpressed with that argument, was "unwilling to deny plaintiff its right to sue merely because it purchased the equipment through a third party rather than directly from the manufacturers."50

The disputes in Missouri v. Stupp Brothers Bridge Es Iron Co. ${ }^{51}$ and Armco Steel Corp. v. North Dakota ${ }^{52}$ arose in 1964 after certain structural steel manufacturers pleaded nolo contendere to government allegations that they had conspired to rig bids and allocate territories in violation of the Sherman Act. In both cases the plaintiffs claimed that the resulting overcharges were passed on to them by the direct purchasers, general contractors,

See McGuire, supra note 21, at 187 n.33.

However, a distinction justified merely on a difference in the requirements of establishing a prima facie case misses the point. In both situations "injury" is the sine gua non of a prima facie case. In overcharge cases "injury" is presumed merely by the fact of the overcharge despite the theoretically valid contention that there may be no real injury. To say that price discrimination may not necessarily injure a plaintiff and that merely proving a discrimination does not, therefore, establish a prima facie case is to say nothing more than that the courts should not presume an injury in discrimination cases. Therefore different treatment in establishing the measure of damages for overcharge and discrimination cases can only be justified by a finding that the probability of injury is greater in overcharge cases.

${ }^{48}$ See, e.g., Armco Steel Corp. v. North Dakota, 376 F.2d 206 (8th Cir. 1967); Washington v. American Pipe and Constr. Co., 274 F. Supp. 961 (W.D. Wash. 1967); Missouri v. Stupp Bros. Bridge \& Iron Co., 248 F. Supp. 169 (W.D. Mo. 1965); Washington v. General Elec. Co., 246 F. Supp. 960 (W.D. Wash. 1965).

49 246 F. Supp. 960 (W'D. Wash. 1965).

${ }^{50} \mathrm{Id}$. at 962.

51248 F. Supp. 169 (W.D. Mo. 1965).

52376 F.2d 206 (8th Cir. 1967). 
in their bid computations on highway projects. In Stupp Brothers the defendant manufacturers, relying on Darnell-Taenzer, claimed that the plaintiffs had no right to sue and asked for dismissal. The court viewed the defendants' argument as based solely on privity and rejected such notions as not consonant with section 4 of the Clayton Act and the general policy of encouraging private actions. Armco was an appeal from a jury award for plaintiff on similar facts. The Court employed the target-area test and had no difficulty finding that plaintiffs had standing. ${ }^{53}$

It is significant that none of these cases gave much weight to the "insurmountable problems of proof" argument. If a plaintiff was within the target area of the conspiracy and appeared willing and able to prove his injury, the courts were willing to let him try. Indeed, the plaintiff in Armco proved his damages before a jury and the Eighth Circuit found the evidence sufficient to support the jury award. ${ }^{54}$

During the same period, however, the conclusion that passing-on might be so difficult to prove that defendants should not be allowed to make the attempt (the notion subsequently adopted by the Supreme Court in Hanover Shoe) was approved by some courts. For example, in a series of cases $^{55}$ public utilities sued equipment manufacturers for treble damages, alleging overcharges on purchases. The defendants hoped to show that the utilities had passed on their increased costs to their users and submitted a series of interrogatories concerning the economic structure of plaintiffs' companies, with particular emphasis on rate bases and rates of return. Given that the general theory of rate setting for public utilities is to allow a reasonable return to the companies, these interrogatories seemed clearly relevant. As one commentator pointed out:

One of the costs of service which a utility recovers is depreciation on capital assets. An appropriate amount is deducted annually from general revenues and charged to a depreciation account. If these annual charges are adequate, the utility will completely recoup amounts expended for capital equipment by the time the assets are retired. Since the funds for this charge are derived

${ }^{53} I d$. at $210-11$.

${ }^{54} I d$.

${ }^{55}$ Commonwealth Edison Co. v. Allis-Chalmers Mfg. Co., 335 F.2d 203 (7th Cir. 1964); Public Util. Dist. No. 1 v. General Elec. Co., 230 F. Supp. 744 (W.D. Wash. 1964); Atlantic City Elec. Co. v. General Elec. Co., 226 F. Supp. 59 (S.D.N.Y.), appeal denied, 337 F.2d 844 (2d Cir. 1964). 
from the utility's ratepayers, a utility does, in a sense, pass on its capital equipment costs . ...56

The court in Commonwealth Edison v. Allis-Chalmers Manufacturing $\mathrm{Co}^{57}$ was nevertheless unimpressed. Anticipating the opinion in Hanover Shoe, the court relied heavily on Darnell-Taenzer ${ }^{58}$ for the proposition that the overcharge, regardless of passing-on, was the appropriate measure of damages. The court was also concerned that the possibility of an ultimate consumer recovery was nonexistent and that "[t]o apply the pass-on defense in these circumstances would be tantamount to immunizing defendants from liability." 59 After stressing the problem of proof, the court concluded that "if there is to be a windfall, plaintiffs as innocent purchasers should receive it rather than defendants."60

Defensive passing-on was by no means dead prior to Hanover Shoe, however. In a group of private suits ${ }^{61}$ that followed a government prosecution of oil producers for fixing prices, ${ }^{62}$ plaintiff oil jobbers (middlemen) sought treble damages measured by the amount of the overcharge to them. The courts, in allowing the passing-on defense, ${ }^{63}$ seemed especially persuaded by the fact that the profit margins of the jobbers were guaranteed. Despite its broad language the Darnell-Taenzer case was uniformly distinguished as relevant only to claims brought under the Interstate Commerce Act. $^{64}$ The passing-on defense was

${ }^{56}$ Note, The "Pass-On" Defense and Regulated Public Utilities, 110 U. PA. L. Rev. $1118,1118-19$ (1962).

"7 335 F.2d 203 (7th Cir. 1964).

${ }^{58}$ Id. at $205-06$.

s"Id. at 208.

${ }^{60} I d$. at 209. Furthermore, the possibilities for retrospective adjustment in the ratemaking context are extremely limited. S' L. Schwartz, Fref ENTERPRISE \& Economic Organization 732-35 (1972). Thus, it appears unlikely that any recovery by an electric utility company would be passed on to its consumers.

${ }^{61}$ Clark Oil Co. v. Phillips Petroleum Co., 148 F.2d 580 (8th Cir.), cert. denied, 326 U.S. 734 (1945); Northwestern Oil Co. v. Socony-Vacuum Oil Co., 138 F.2d 967 (7th Cir. 1943), cert. denied, 321 U.S. 792 (1944); Twin Ports Oil Co. v. Pure Oil Co., 119 F.2d 747 (8th Cir.), cert. denied, 314 U.S. 655 (1941); Leonard v. Socony-Vacuum Oil Co., 42 F. Supp. 369 (W.D. Wis.), appeal dismissed, 130 F.2d 535 (7th Cir. 1942). 62 United States v. Standard Oil Co., 23 F. Supp. 937 (W.D. Wis. 1938), aff'd sub nom. United States v. Socony-Vacuum Oil Co., 310 U.S. 150 (1940).

${ }^{63}$ One court implied that the burden of proof was on the plaintiffs to show that they did not pass on their higher costs. Leonard v. Socony-Vacuum Oil Co., $42 \mathrm{~F}$. Supp. 369, 370 (W.D. Wis. 1942), appeal dismissed, 130 F.2d 535 (7th Cir. 1942).

${ }^{64}$ Cf. Northwestern Oil Co. v. Socony-Vacuum Oil Co., 138 F.2d 967, 970 (7th Cir. 1943), cert. denied, 321 U.S. 792 (1944):

The carrier is bound to establish published rates and, if these prove to be improper, the shipper is, by statute, in jure proprio, granted the right to recover. . . . This remedy, as a matter of law, is lodged only in those in priv- 
also allowed in Freedman v. Philadelphia Terminals Auction Co. ${ }^{65}$ The plaintiffs in that case, fruit brokers, alleged that the defendants had charged prices in excess of those allowed under section 2 of the Clayton Act. Because the brokers operated on a fixed mark-up arrangement, however, the court found that they had not been injured in their "business or property." 66

A review of these cases suggests that the law of defensive passing-on was not radically altered by Hanover Shoe. Where the proof of passing-on was difficult, as in the "electrical cases," 67 the defense was not allowed. Where the facts of the case showed a cost-plus or analogous arrangement, as in the "oil jobber cases" 68 and Freedman, the defense was allowed. When viewed in this historical perspective, therefore, the ultimate effect of the Hanover Shoe opinion should be little more than an affirmation of these distinctions and, perhaps, a narrowing of the number and scope of the exceptions to the general policy disfavoring the defense. As will be demonstrated, however, the state of the law with regard to the offensive use of passing-on remains unsettled and extreme caution must be exercised lest superficial interpretations of Hanover Shoe result in a rule of standing that needlessly disadvantages indirect purchasers.

\section{Offensive Passing-On After Hanover Shoe}

Lower court decisions since Hanover Shoe disagreed as to its effect on the standing of indirect purchasers. ${ }^{69}$ The cases de-

ity with the carrier, whereas the action under the Clayton Act is one in tort, not to recover an overcharge as such, but to collect damages sustained to plaintiff's property or business.

6. 30 I F.2d 830 (3d Cir. 1962).

${ }^{66} I d$. at 833.

${ }^{67}$ See note 55 supra.

${ }^{68}$ Ser note 61 supra.

${ }^{6 "}$ "The following cases held that Hanover Shoe forecloses plaintiffs from showing passing-on: Donson Stores, Inc. v. American Bakeries Co., 58 F.R.D. 481 (S.D.N.Y. 1973); Balmac, Inc. v. American Metal Prods. Corp., 1972 Trade Cas. I 74,235 (N.D. Cal. 1972); Denver v. American Oil Co., 53 F.R.D. 620 (D. Colo. 1971); Philadelphia Housing Authority v. American Radiator \& Standard Sanitary Corp., 50 F.R.D. 13 (E.D. Pa. 1970), aff'd sub nom. Mangano v. American Radiator \& Standard Sanitary Corp., 438 F.2d 1187 (3d Cir. 1971); United Egg Producers v. Bauer Int'l Corp., 312 F. Supp. 319 (S.D.N.Y. 1970); Philadelphia Housing Authority v. American Radiator \& Sanitary Corp., 323 F. Supp. 381 (E.D. Pa. 1970). Cf. Stern v. Lucy Webb Hayes Nat'l Training School, 367 F. Supp. 536 (D.D.C. 1973); City of Akron v. Laub Baking Co., 1972 Trade Cas. I 73,930 (N.D. Ohio 1972). In Travis v. Fairmount Foods Co., 346 F. Supp. 679 (E.D. Pa. 1972), the plaintiffs conceded the issue.

Holding that Hanover Shoe does not restrict standing are: In re W'estern Liquid Asphalt Cases, 487 F.2d 191 (9th Cir. 1973), cert. denied, 415 U.S. 919 (1974); In re 
nying standing to such plaintiffs have relied on three arguments. First, it is claimed that Hanover Shoe held as a matter of law that proof of passing-on is impossible absent a cost-plus or similar fixed markup arrangement. ${ }^{70}$ Second, it has been asserted that, through its reliance on Darnell-Taenzer, ${ }^{71}$ Hanover revived the privity requirement of standing. Third, it is argued that affording standing to indirect purchasers while denying the defendant the opportunity to show that a particular purchaser passed on the overcharge would expose defendants to serious risks of multiple liability. ${ }^{72}$

The cases that permit indirect purchasers an opportunity to show a pass-on attach a markedly different significance to Hanover Shoe. The courts in these cases see the decision as one in a long line of cases whose connecting principle is the protection of the treble-damage remedy as a primary enforcement mechanism of the antitrust laws. ${ }^{73}$ The notion that privity is a prerequisite to standing is rejected outright. ${ }^{74}$ Although the opinions also generally reject the proposition that Hanover Shoe held that proof of passing-on is impossible as a matter of law, the facts in these cases. were stated in a manner suggesting an attempt to fit them within the cost-plus exception. ${ }^{75}$ The multiple liability problem has generally been skirted as being too

Master Key Antitrust Litigation, 1973-2 Trade Cas. I 74,680 (D. Conn. 1973); Boshes v. General Motors Corp., 59 F.R.D. 589 (N.D. Ill. 1973); Southern Gen. Builders, Inc. v. Maule Indus. Inc., 1973-1 Trade Cas. ๆ 74,484 (S.D. Fla. 1972). Cf. West Virginia v. Chas. Pfizer \& Co., 440 F.2d 1079 (2d Cir. 1971), cert. denied, 404 U.S. 871 (1971); Sol S. Turnoff Drug Distrib. Inc. v. N.V. Nederlandsche Combinatie Voor Chemische Industrie, 51 F.R.D. 227 (E.D. Pa. 1970).

${ }^{70}$ See, e.g., Donson Stores, Inc. v. American Bakeries Co., 58 F.R.D. 481, 484 (S.D.N.Y. 1973); Balmac, Inc. v. American Metal Prods. Corp., 1972 Trade Cas. If 74.235, at 93,062-63 (N.D. Cal. 1972); Philadelphia Housing Authority v. American Radiator \& Standard Sanitary Corp., 50 F.R.D. 13, 25-26 (E.D. Pa. 1970).

${ }^{7}$ See, e.g., Denver v. American Oil Co., 53 F.R.D. 620, 631 (D. Colo. 1971); Philadelphia Housing Authority v. American Radiator \& Standard Sanitary Corp., 50 F.R.D. 13, 30 (E.D. Pa. 1970), aff'd sub nom. Mangano v. American Radiator \& Standard Sanitary Corp., 438 F.2d 1187 (3d Cir. 1971).

${ }^{72}$ See, e.g., Donson Stores, Inc. v. Ämerican Bakeries Co., 58 F.R.D. 481, 484 (S.D.N.Y. 1973); Denver v. American Oil Co., 53 F.R.D. 620, 638 (D. Colo. 1971).

${ }^{73}$ See, e.g., In re Western Liquid Asphalt Cases, 487 F.2d 191, 197 (9th Cir. 1973), cert. denied, 415 U.S. 919 (1974); In re Master Key Antitrust Litigation 1973-2 Trade Cas. If 74,680, 94,979 (D. Conn. 1973); Boshes v. General Motors Corp., 59 F.R.D. 589, 596 (N.D. Ill. 1973).

74 "[I]t would be stretching Hanover Shoe beyond all recognition to hold that its rejection of the passing-on defense somehow returns $\S 4$ of the Clayton Act to the "days when "privity" was king. . . " Boshes v. General Motors Corp., 59 F.R.D. 589,596 (N.D. Ill. 1973).

${ }^{75}$ In re Western Liquid Asphalt Cases, 487 F.2d 191, 196 (9th Cir. 1973), cert. denied, 415 U.S. 919 (1974); In re Master Key Antitrust Litigation, 1973-2 Trade Cas. 
hypothetical or as being capable of solution through existing procedural mechanisms. ${ }^{76}$

\section{The Correct Interpretation of Hanover Shoe As It Relates to Standing}

Although legitimate policy considerations exist for denying standing to indirect purchasers, reliance on Hanover Shoe as a mandate, or even as a suggestion, for this result is misplaced.

The Court in Hanover Shoe was responding to the legal argument of a defendant against whom a prima facie case of liability had already been made out. ${ }^{77}$ The holding of the case is not relevant to the standing of a plaintiff seeking to prove his injury, and discussion of the case in this context has generally distorted the debate on the standing issue.

Whatever else might be said of Hanover Shoe, one thing is certain: it did not hold that privity is a requirement for standing under section 4 of the Clayton Act. Indeed, the Supreme Court has directly addressed the standing issue in this context only once, in Hawaii $v$. Standard Oil $\mathrm{Co}^{78}$ (In that case it was held that the state of Hawaii was precluded from suing in parens patriae for damage to its general economy caused by violations of the Act.) To reinstate a privity requirement based on Hanover Shoe's reliance upon Darnell-Taenzer ${ }^{79}$ - a case decided in 1917 which itself had nothing to do with standing or with the Clayton Act-is to draw a far-reaching conclusion from mere inference and dicta.

Under the Court's reasoning in Hanover, defendants are indeed confronted with such severe problems of proof that it is justifiable to consider their task virtually impossible. This is so because the Court concluded that defendants must show not only that the plaintiff passed on the overcharge to his customers,

I 74,680, at 94,980 (D. Conn. 1973); Boshes v. General Motors Corp., 59 F.R.D. 589, 597 (N.D. Ill. 1973).

${ }^{76}$ In $r e$ Western Liquid Asphalt Cases, 487 F.2d 191, 201 (9th Cir. 1973), cert. denied, 415 U.S. 919 (1974); In $r e$ Master Key Antitrust Litigation, 1973-2 Trade Cas. If 74,680. at 94,979 (D. Conn. 1973); Boshes v. General Motors Corp., 59 F.R.D. 589, 596-97 (N.D. Ill. 1973).

is The Clayton Act provides that "a final judgment . . rendered in any civil or criminal proceeding brought by or on behalf of the United States under the antitrust laws . . shall be prima facie evidence against such defendant . . ." 15 U.S.C. $\S 16(a)$ (1970). The government had secured an antitrust judgment against the defendant United Shoe. United States v. United Shoe Mach. Corp., 110 F. Supp. 295 (D. Mass. 1953), aff'd per curiam, 347 U.S. 521 (1954).

${ }^{78} 405$ U.S. 251 (1972).

7" Text accompanying note 34 supra. 
but also that the plaintiff would not and could not have raised his prices absent the overcharge. ${ }^{80}$ As the Court reviewed the matter,

[t]he mere fact that a price rise followed an unlawful cost increase does not show that the sufferer of the cost increase was undamaged. His customers may have been ripe for his price rise earlier; if a cost rise is merely the occasion for a price increase a businessman could have imposed absent the rise in his costs, the fact that he was earlier not enjoying the benefits of the higher price should not permit the supplier who charges an unlawful price to take those benefits from him without being liable for damages. This statement merely recognizes the usual principle that the possessor of a right can recover for its unlawful deprivation whether or not he was previously exercising it. ${ }^{81}$

Plaintiffs, on the other hand, need only show that their injury was proximately caused by the illegal acts of the defendant. ${ }^{\mathbf{2}}$ A plaintiff must introduce evidence that will show with a "reasonable probability" 83 or with a "fair degree of certainty" 84 that the defendant's illegal acts were a material cause of some damage $^{85}$ to him. The evidence introduced may be circumstantial in nature. ${ }^{86}$ There is no justification for assuming that a secondary

${ }^{80} 392$ U.S. at 493. See, e.g., Wall Prods. v. National Gypsum Co., 326 F. Supp. 295

(N.D. Cal. 1971). See also McGuire, supra note 21, at 185-86.

81392 U.S. at 493 n.9.

${ }^{82}$ See, e.g., Glenn Coal Co. v. Dickinson Fuel Co., 72 F.2d 885, 887 (4th Cir. 1934); Fiumara v. Texaco, Inc., 204 F. Supp. 544, 547 (E.D. Pa.), aff'd per curiam, 310 F.2d 737 (3d Cir. 1962).

${ }^{83}$ E.V. Prentice Mach. Co. v. Associated Plywood Mills, 252 F.2d 473, 477 (9th Cir.), cert. denied, 356 U.S. 951 (1958); Flintkote Co. v. Lysfjord, 246 F.2d 368, 392 (9th Cir. 1957), cert. denied, 355 U.S. 835 (1957).

${ }^{84}$ Momand v. Universal Film Exchs., 172 F.2d 37, 43 (1st Cir. 1948), cert. denied, 336 U.S. 967 (1949).

${ }^{85}$ Zenith Radio Corp. v. Hazeltine Research, Inc., 395 U.S. 100, 114 n.9 (1969).

${ }^{86}$ In Bigelow v. RKO Radio Pictures, Inc., 327 U.S. 251, 264 (1946), the Court suggested that:

the jury could conclude as a matter of just and reasonable inference from the proof of defendants' wrongful acts and their tendency to injure plaintiffs' business, and from the evidence of the decline in prices, profits and values, not shown to be attributable to other causes, that defendants' wrongful acts had caused damage to the plaintiffs (emphasis supplied).

In a similar setting the Court pointed out that "the injury alleged . . . was precisely the type of loss that the claimed violations of the antitrust law's would be likely to cause. The trial court was entitled to infer from this circumstantial evidence that the necessary causal relation between the ... conduct and the claimed damage existed." Zenith Radio Corp. v. Hazeltine. 395 U.S. 100, 125 (1969) (emphasis supplied). 
purchaser cannot meet this burden of proof. First, a plaintiff located along the chain of distribution need not show that a defendant's illegal overcharge was the sole cause of a price increase in the product purchased by the plaintiff. It is enough to show that the overcharge was a material factor. ${ }^{87}$ Second, the plaintiff should be aided, perhaps, by a general presumption that higher prices at one level in a chain of distribution result in higher prices at lower levels.

This process of proof is not, of course, a simple one. It can indeed require "complicated proceedings involving massive evidence and complicated theories." 88 However, that fact alone does not distinguish a plaintiff seeking to prove passing-on from any other plaintiff involved in a treble-damage action. Most treble-damage actions are complicated affairs and many require the use of sophisticated analytical techniques in order that the probable course of events which would have occurred absent the illegal acts may be recreated. ${ }^{89}$ As one commentator has pointed out, "the concept of antitrust 'injury' necessarily consists in large part of hope, projections and blue sky . . . ."90 Thus, an argument that would deny standing to plaintiffs, because the injuries for which they seek redress are difficult to prove, proves too much and has widespread implications for the treble-damage action which the Court in Hanover Shoe could hardly have intended.

The Supreme Court has recognized that the antitrust laws express the fundamental economic policy of the nation. ${ }^{91}$ It has also recognized that the private action for treble damages is of paramount importance in the enforcement of that policy: ${ }^{92}$ "[T] he purposes of the antitrust laws are best served by insuring that the private action will be an ever-present threat to deter

${ }^{87}$ Perma Life Mufflers, Inc. v. International Parts Corp., 392 U.S. 134, 143-44 (1968) (White, J., concurring). This concurrence was cited with approval by the Zenith court. 395 U.S. at 114 n.9. See also Comment, Monetary Recovery Under Federal Antitrust Statutes, 45 Texas L. Rev. 856, 861 (1967).

88392 U.S. at 493.

${ }^{89}$ See generally Lanzillotti, Problems of Proof of Damages in Antitrust Suits, 16 ANTITRUST BULL. 329, 330-32 (1971).

90 Pollock, The "Injury" and "Causation" Elements of a Treble-Damage Antitrust Action, 57 Nw. U.L. Rev. 691,695 (1963).

91 Northern Pac. Ry. v. United States, 356 U.S. 1, 4 (1958).

92 Zenith Radio Corp. v. Hazeltine Research, Inc., 395 U.S. 100, 130-31 (1969); Hanover Shoe Inc. v. United Shoe Mach. Corp., 392 U.S. 481, 494 (1968); Perma Life Mufflers, Inc. v. International Parts Corp., 392 U.S. 134, 139 (1968); Minnesota Mining \& Mfg. Co. v. New Jersey Wood Finishing Co., 381 U.S. 311,318 (1965); Radovich v. National Football League, 352 U.S. 445, 453-54 (1957). 
anyone contemplating business behavior in violation of the antitrust laws." 93 In its rejection of the passing-on defense, Hanover Shoe's basic aim was to protect the treble-damage remedy. When viewed in this light, the decision is consistent with a long line of cases easing the way for private antitrust plaintiffs. ${ }^{94}$ It is not without some irony, therefore, that the case has subsequently been used as a major weapon against many of these plaintiffs. As one court has stated: "The attempt to transform a rejection of a defense because it unduly hampers antitrust enforcement into a reason for a complete refusal to entertain the claims of a certain class of plaintiffs seems an ingenious attempt to turn the decision and its underlying rationale on its head." 95

\section{Why Hanover Shoe Has BeEn Misinterpreted}

If, as has been argued, Hanover Shoe is so clearly inapplicable to plaintiffs, the question naturally arises: Why did some courts nevertheless use the case to deny standing? Although a consideration of that question requires some speculation, the cases make the answer fairly apparent. First, the courts were concerned with the serious problem that defendants might be the victims of multiple liability. Hanover Shoe gave immediate purchasers the right to recover damages regardless of real injury; if plaintiffs further along the chain of distribution are also allowed to sue, the multiple liability problem would seem to follow. Second, the facts of the cases denying secondary purchasers standing suggest that the courts had serious doubts that plaintiffs were presenting manageable and meritorious actions. ${ }^{96}$ Hanover Shoe may have served as a handy peg upon which to hang these concerns. It is the thesis of this Comment that the problem of multiple liability is amenable to solution, and that tampering with the theory of standing is not a satisfactory answer to the problem of manageability.

\section{A. The Problem of Multiple Liability}

The decisions that afford standing to secondary purchasers have not supplied totally satisfactory solutions to the problem of multiple liability. The courts in Boshes v. General Motors Corp. ${ }^{97}$

93 Perma Life Mufflers, Inc. v. International Parts Corp., 392 U.S. 134, 139 (1968).

94 See cases cited note 92 supra.

9s In re Master Key Antitrust Litigation, 1973-2 Trade Cas. If 74,680, at 94,978-79

(D. Conn. 1973).

${ }^{96}$ See text accompanying notes 118-21 infra.

9759 F.R.D. 589 (N.D. Ill. 1973). 
and In re Master Key Antitrust Litigation ${ }^{98}$ were not particularly troubled by the problem, believing that the mere hypothetical possibility of multiple recovery was not of sufficient importance to be considered at a preliminary stage of the litigation. ${ }^{99}$ Moreover, both courts were convinced that such procedural devices as statutory interpleader, the statute of limitations, or the doctrine of collateral estoppel would suffice to ameliorate the problem. ${ }^{100}$

At best, however, the availability of these devices presents only a partial answer. Statutory interpleader ${ }^{101}$ is a device by which defendants can bring all claimants into a single forum and require them to litigate inter se the proper distribution of the fund. However, as has been pointed out by one commentator, ${ }^{102}$ interpleader may not be either a fair or a practical alternative for defendants. That a defendant has the option of interpleading may, in some instances, do no more than offer him the Hobson's choice of either attempting to construct a complex class action by bringing in the ultimate consumers of his product and paying a bond for the amount in controversy ${ }^{103}$ or risking the payment of damages to each potential plaintiff in a line of distribution. Moreover the whole attempt could come to naught if it is found that the class action is not a manageable one. ${ }^{104}$ Finally, interpleader is useful only where the defendant is willing to concede the antitrust violation and the amount of the damages is clear. ${ }^{105}$

Under the relevant statute of limitations, plaintiffs have four years to commence suit following the accrual of the cause of action. ${ }^{106}$ That, as a practical matter, plaintiffs will sleep on their rights and be time-barred from bringing an action is not a theoretically satisfactory answer to the problem of multiple liability. The Boshes and Master Key courts were able to rely on

98 1973-2 Trade Cas. $\uparrow 74,680$ (D. Conn. 1973).

9959 F.R.D. at 596-97; 1973-2 Trade Cas. at 94,979.

10059 F.R.D. at 596-97; 1973-2 Trade Cas. at 94,979.

10128 U.S.C. $\S 1335$ (1970).

${ }^{102}$ McGuire, supra note 21 , at 197.

${ }^{103} 28$ U.S.C. $\S 1335(\mathrm{a})(2)(1970)$; 3 A J. Moore, Federal Practice $\llbracket 22.10(2 \mathrm{~d}$ ed. 1974).

${ }^{104}$ Fed. R. Civ. P. 23(b)(3)(D). See, e.g., Eisen v. Carlisle \& Jacquelin, 417 U.S. 156 (1974).

${ }^{105}$ See 28 U.S.C. $\$ 1335$ (a)(2) (1970).

10615 U.S.C. $\$ 15$ (b) (1970). The statute is suspended during the pendency of a government proceeding and a year thereafter. However, the action must be brought within four years of the accrual of the action or within the suspension period. 15 U.S.C. $\S 16(b)(1970)$. 
the statute because of the particular facts of the litigations involved, but such will not always be the case.

The most startling suggestion made by the Boshes and Master Key courts is that defendants will be protected from multiple liability by operation of the doctrine of collateral estoppel in cases where the secondary purchaser sues first. " $[\mathrm{A}]$ jury finding that an overcharge had been passed-on, particularly by a party in contractual privity with the alleged antitrust violator, would preclude relitigation of the same issue by the 'passing-on' party (e.g. the initial purchaser) who is higher up in the distribution chain."107 However, although Blonder-Tongue Labs, Inc. v. University of Illinois Foundation ${ }^{108}$ held that estoppel may be asserted against a party in privity with a party in a prior action on the same facts, the mere fact that primary and secondary purchasers have business contracts hardly provides the necessary identity of interest which would justify denying the primary purchaser his day in court. ${ }^{109} \mathrm{~A}$ more persuasive argument could, perhaps, be made by appealing directly to the policies underlying a determination of collateral estoppel: that the defendant in a suit brought by a secondary purchaser has substantially similar interests in combatting an allegation of passing-on as would the primary purchaser, were he a party to the litigation. Furthermore, he has little to lose in doing so, since Hanover Shoe bars him from asserting a pass-on as a defense to the claim of the primary purchaser. On the other hand, a jury finding that the overcharge was passed on is of questionable relevance to the right of a primary purchaser to recover. In this instance the Hanover Shoe presumption that the measure of damages is the amount of the overcharge seems inapplicable. That the primary purchaser raised his prices in response to an overcharge does not mean he did not suffer injury. ${ }^{110}$

\section{B. Apportionment of Damages Among Potential Plaintiffs}

In re Western Liquid Asphalt Cases, ${ }^{111}$ the Ninth Circuit confronted the issue directly. It granted various states and municipalities standing to sue for overcharges that originated at the manufacturing level and which were allegedly passed on by

\footnotetext{
${ }^{107}$ Boshes v. General Motors Corp., 59 F.R.D. 589, 596 (N.D. Ill. 1973).

108402 U.S. 3 I 3 (1971).

109 1B J. Moore, Federal Practice If 0.411[1] (2d ed. 1974).

110 See note 27 supra.

111487 F.2d 191 (9th Cir. 1973), cert. denied, 415 U.S. 919.
} 
road contractors in their bids for highway projects. Since some of the contractor-primary purchasers were involved in the action, the court felt obliged to advise the lower court on the proper method of allocating damages:

[T] he amount of the overcharge is not necessarily the total amount of harm to plaintiffs. Purchasers may also have been damaged by being forced to turn to substitute goods, or to discontinue purchasing the pricefixed product. The essence of conspiracy is that the conspirators believe they will recover more from the illegal overcharge than they will lose from diminished sales. Hanover Shoe . . . indicates that the measure of damages includes lost profits. Thus, in passing-on cases, the intermediary should recover the amount of the overcharge that was not passed on, if the proof shows that the ultimate consumer did not pay it all, and any lost profits resulting from increased costs. The ultimate purchasers should obtain the remainder of the overcharge, and any other damages proximately caused. ${ }^{112}$

This approach has the advantage of promoting a just apportionment of the overcharges in a context where everyone recovers his proven damages and the wrongdoer gets his just deserts. It is subject, however, to the criticism that it limits the general principle established by Hanover Shoe, that primary purchasers are entitled to recover the entire amount of the overcharge without regard to any pass-on. ${ }^{113}$ Nevertheless, Hanover Shoe did not address the situation where both primary and secondary purchasers are involved as plaintiffs, and deviance from the general principle of damages stated in that case, seems justified where the policies of deterrence and compensation can be accommodated.

An apportionment similar to that suggested in In re Western Liquid Asphalt Cases should suffice in cases where both primary and secondary purchasers are involved as plaintiffs. To promote a more equitable apportionment of the damages, therefore, courts should not hesitate to allow intervention ${ }^{114}$ by secondary purchasers in actions brought by the primary purchasers and, of course, vice versa.

112 Id. at 200-01.

11392 U.S. at 491.

114 Fed. R. Civ. P. 24(b). 
Where the primary purchasers bring their actions first and no secondary purchasers have intervened, secondary purchasers who bought from primary purchasers that recovered should be barred from bringing their actions against the original defendant for the express reason of avoiding double liability. ${ }^{115} \mathrm{Al}$ though this result might be criticized, it is less harsh than that contemplated by those courts that deny standing to all secondary purchasers. Of course, secondary purchasers would be granted standing if no party in their particular chain of distribution had recovered. Moreover, once a party secures a judgment the recovery should be safe from further actions by parties further down the chain of distribution. Otherwise primary purchasers may hesitate to sue, fearing that their recovery will be significantly diminished by parties waiting on the sidelines who have not shared the costs of litigation. As emphasized by the Court in Hanover Shoe, primary purchasers are usually the best plaintiffs to ensure the enforcement of the antitrust laws, and, in view of recent decisions defining the burdens of managing a large class action, in some cases they may effectively be the only plaintiffs available.

Where secondary purchasers sue first and obtain a judgment without intervention by primary purchasers, several solutions seem possible. First, primary purchasers might be barred from bringing suit against the defendant on the ground that double recovery might otherwise ensue. Such a rule might have the added effect of encouraging the supposedly best plaintiff, the primary purchaser, to enter the litigation at an early stage. But less drastic alternatives are available. Primary purchasers could be limited in their recovery to proven lost profits and not be allowed to rely on the amount of the overcharge as the measure of damages. This course, however, runs counter to the decision in Hanover Shoe insofar as it creates an irrefutable presumption that the amount of the overcharge is the appropriate measure of damages. As was suggested earlier, Hanover Shoe need not be read as establishing an absolute rule for the measure of damages. Indeed, this situation might be viewed in the same light as the cost-plus exception. The danger of multiple liability can also be avoided if the defendant exercises his option of statutory interpleader. The difficulties that attach to the use of interpleader have already been noted. ${ }^{116}$ Finally,

"15 See McGuire, supra note 21, at 198.

${ }^{116}$ See text accompanying notes 101-05 supra. 
and perhaps most satisfactorily, the burden could be shifted to the defendant. If sued by a secondary purchaser, a defendant could join the primary purchaser that sold to the plaintiff-the only instance where multiple liability is possible-as a party necessary for a just adjudication of the matter. ${ }^{117}$ This might expose the defendant to a larger total liability, but the decision is his own and if no joinder is made, he should not later be heard to complain of multiple liability.

\section{Problems of Proof and Standing Revisited}

The question remains whether it is ever justifiable to assume that plaintiffs cannot prove their cases ${ }^{118}$ and therefore to deny them standing. Philadelphia Housing Authority v. American Radiator and Standard Sanitary Corp. ${ }^{119}$ is on point in this regard. The plaintiffs in that case were homeowners who claimed that they were entitled to recover illegal overcharges by manufacturers of plumbing fixtures which were used in the construction of their houses. The alleged chain of distribution extended from the defendants to wholesalers to contractors to builders to prior homeowners to the plaintiffs. The court dismissed the case, stating that:

[i]t would be incredible if the price of a house were determined not by the shifts in supply in [sic] demand in the market for homes as a whole but rather by a relatively miniscule change (with regard to the selling price of the house) in the price of the plumbing fixtures. If the Supreme Court regarded the figures underlying corresponding assumptions as "virtually unascertainable" and applied such adjectives as "insuperable" and "insurmountable" to any attempt to support them in that case, it certainly follows a fortiori that insuperable difficulties inhere in the premises underlying the claims at issue in the instant case. ${ }^{120}$

One would be hard put to argue with this perception of the case and, given the present burden on our court system, it is easy to sympathize with the result. The facts of Philadelphia Housing Authority, however, present the most extreme case imaginable.

117 Fed. R. Civ. P. 19.

${ }^{18}$ Sec text accompanying notes 80-90 supra.

11: 50 F.R.D. 13 (E.D. Pa. 1970), aff'd sub nom. Mangano v. American Radiator \&. Sanitary Corp., 438 F.2d 1187 (3d Cir. 1971).

${ }^{120} I d$. at 26. 
To transform its conclusion into a rule of law governing the standing of secondary purchasers would, therefore, reach too far; the facts of the next case may be far less compelling.

The difficulties that inhere in making such an a priori assessment of the problems of proof in this setting are further demonstrated by the conflicting decisions in the "asphalt cases." In City and County of Denver v. American Oil Co. ${ }^{121}$ plaintiffs alleged that defendant oil companies had conspired to fix the price of asphalt. Plaintiffs claimed that the illegal overcharge was passed on to them through the bids of general contractors employed in various highway projects. The court dismissed the suit, citing a lack of privity. ${ }^{122}$ The court also expressed concern, however, with what it considered to be extremely difficult problems of proof:

The difficulty in tracing any overcharge for asphalt into a completed job will vary from job to job. On a repaving job, the cost of asphalt would have to be broken out of the paving bid, and inquiry would have to be made as to how that cost influenced the bid. This would not be simple, but, as compared to tracing the cost of asphalt into the cost of a 10-mile stretch of a new highway blasted out of the Colorado mountains, the problem would be child's play. ${ }^{123}$

On essentially similar facts, the court in In re Western Liquid Asphalt Cases $^{\mathbf{1 2 4}}$ reached exactly the opposite conclusion. Despite the fact that the district court had clearly expressed its opinion that the problems of proof were similar in their complexity to those presented by the facts in Hanover Shoe, ${ }^{\mathbf{1 2 5}}$ the court found no overwhelming problems of proof. In its view the facts suggested a situation much like the cost-plus exception cited in Hanover Shoe. ${ }^{126}$

The asphalt cases point up the danger of determining, on the pleadings, that a certain set of facts cannot be proven. If standing is to be determined according to a judge's a priori notion of the difficulty of proof, the result is likely to be a morass of contradictory opinions and impenetrable distinctions. Cer-

\footnotetext{
12153 F.R.D. 620 (D. Colo. 1971).

122 Id. at 631 .

${ }^{123}$ Id. at $636-37$.

${ }^{124} 487$ F.2d 191 (1973), cert, denied. 415 U.S. 919 (1974).

${ }^{12.5}$ In $r e$ Western Liquid Asphalt Cases. 350 F. Supp. 1369, 1372 (N.D. Cal. 1972).

126487 F.2d at 196.
} 
tainty therefore requires that passing-on as a theory of recovery either be accepted or rejected in toto. It has been the thesis of this Comment that the policies of encouraging enforcement of the antitrust laws and of compensating the victims of their violation support acceptance.

\section{Conclusion}

In an era when the public enforcement of the antitrust laws is largely problematical, ${ }^{\mathbf{1 2 7}}$ private enforcement proceedings become increasingly important. ${ }^{128}$ Therefore any burden on private actions should be imposed only upon compelling considerations.

There are no compelling considerations which would justify denying standing to indirect purchasers merely because they are indirect purchasers. Hanover Shoe does not address the question and, when read in the context of other cases decided by the Court, leans more toward granting standing than toward denying it. Moreover, the policy considerations which led some of the lower courts to deny standing should not overcome the weight that should be accorded to the policy of promoting enforcement. The problem of multiple liability is subject to solution. Although the problem of the judicial burdens caused by plaintiffs seeking to show a pass-on may in some cases be significant, the burdens are not particularly different from those involved in any complicated antitrust proceeding.

$\overline{1}^{12 \bar{z}} \vec{S}_{e e}$ generally M. Green, B. Moore \& B. WASSERstein, The Closed ENTERPRise SYSTEM (1972).

${ }^{128}$ See address by Richard W. McLaren before the Antitrust Committees of the Federal Bar Association and the Philadelphia Bar Association, Dec. 11, 1969, quoted in Parker, Treble Damage Action-A Financial Deterrent to Antitrust Violations? 16 ANTITrust Bull. 483 (1971). 